\section{SOI: $\underline{1.1 / \mathrm{TAS}}$ DOI: $\underline{10.15863 / \mathrm{TAS}}$ International Scientific Journal Theoretical \& Applied Science}

p-ISSN: 2308-4944 (print) ｅ-ISSN: 2409-0085 (online)

Year: 2015 Issue: 03 Volume: 23

Published: $30.03 .2015 \quad \underline{\text { http://T-Science.org }}$

SECTION 11. Biology. Ecology. Veterinary
Vladimir Nikolaevich Sorokopudov

Doctor of Agricultural Sciences, professor,

All-Russian Breeding and Technological Institute of Horticulture and Nursery, Moscow, Russia sorokopudov2015@yandex.ru

Tatyana Alekseevna Kuznetsova Doctor of biological sciences, assistant, St. Petersburg State University of Trade and Economics, St. Petersburg, Russia tano_lovely@mail.ru

Svetlana Nikolayeva Shlapakova

Doctor of biological sciences, associate professor, Faculty of Forestry, Bryansk State Academy of Engineering and Technology, Bryansk, Russia shla-svetlana@yandex.ru

Thi Chuc Nguyen

PhD, Faculty of Forestry, Bryansk State Academy of Engineering and Technology, Bryansk, Russia chucnt1987@gmail.com

\title{
MORPHO-ANATOMICAL AND ECOLOGICAL FEATURES OF THE SPECIES OF THE GENUS JUGLANS L. IN THE CONDITIONS OF BELGOROD REGION
}

\begin{abstract}
For the first time, the study of morphology and biology of six species of the genus Juglans $L$.: J. regia L., J. mandshurica Maxim., J. sieboldiana Maxim., J.cinerea L., J. nigra L., J. rupestris Engelm was conducted in the conditions of the Belgorod region. Rhythm of seasonal development, drought tolerance and yields were identified. Leaf trichomes of six species of the genus Juglans L. were described. A preparation method of leaf epidermis of the genus Juglans $L$ was modified. New data on quantitative and qualitative indicators of fruits was observed including: morpho-structural components, productivity and tolerance to unfavorable conditions in the Belgorod region. Morpho-anatomical structure of the leaves was studied by using the SEM Quanta $2003 D$, the Carl Zeiss microscope.

Key words: genus Juglans L, leaf, trichomes, stomata, drought tolerance.

Language: English

Citation: Sorokopudov VN, Kuznetsova TA, Shlapakova SN, Nguyen TC (2015) MORPHO-ANATOMICAL AND ECOLOGICAL FEATURES OF THE SPECIES OF THE GENUS JUGLANS L. IN THE CONDITIONS OF BELGOROD REGION. ISJ Theoretical \& Applied Science 03 (23): 72-82.
\end{abstract}

Soi: http://s-o-i.org/1.1/TAS*03(23)15 Doi: crossef http://dx.doi.org/10.15863/TAS.2015.03.23.15

\section{Introduction}

Breeding tolerant and high-yielding species with high quality fruits of the genus Juglans L walnut are topical issues $[2$, p.60-62; 15 , p.179-180; 16, p.444448]. Walnut plantations and tree improvement are parts of measurement systems to increase food production. Walnut trees are valuable, due to their content of biologically active substances such as fats, proteins, carbohydrates, vitamins and minerals. Additionally, the fruits are ideal for use in a healthy balanced diet. They also have technologically important features. Walnut oil is highly valued in the food and confectionery industries. Wood of the species of the genus Juglans L is unsurpassed in beauty and quality, used for production of high-grade furniture, decoration of office space, and the airplanes' cabin, yachts, parquet [5; 15, p.179-180].
To increase the diversity of food production, especially in years with abnormal weather conditions, the introduction of plants was held in the Belgorod region. In the Belgorod region, there are no walnut plantations; walnuts are mainly found in private households, and occasionally used in landscaping streets. The purpose of this study is to identify morpho-anatomical and ecological characteristics of some species of the genus Juglans. $\mathrm{L}$ in the conditions of Belgorod oblast.

\section{Materials and methods}

Experimental studies were carried out in the Belgorod State University in the period 2009-2013. Field and pot experiments were carried out in the botanical garden of Belgorod State University. The study of the leaf anatomy was conducted in the nanocenter "BSU". 
The objects of study were six species of the genus Juglans L, growing in the botanical garden NSU "BSU.": J. regia L., J. manshurica Maxim, J. sieboldiana Maxim, J.cinerea L., J. nigra L., J. rupestris Engelm. Species names are given in accordance with the nomenclature «GRIN Taxonomy for Plants». Morphological measurements were made, according to the "Method for studying agerelated changes in plants by morphological signs"[10-14].

The basis of anatomical studies is a technique of collecting material and anatomical research methods, a plan describing the structure of the leaf and data processing method. A study of leaf structures was conducted by using a light microscope Biola Lomo D11U11, Micromed-5, binocular IAS 10; morphometric measurements were made using a micrometer screw MOB-1-16×. Morphological and anatomical description of trichomes was performed using CM "Biola C 13" and SEM Quanta 200 3D in the center of collective use "BSU".

\section{Results and discussions}

Morpho-anatomical features of leaves of the species of the genus Juglans $L$
Characteristics of leaf mesophyll: Leaf of plants of the genus Juglans has dorsoventral structure. The degree of differentiation of palisade mesophyll; the ratio of palisade and spongy mesophylls differ, depending on the plant species and habitat features. Xeromorphic leaves tend to have more highly developed palisade tissue than mesomorphic leaves do. The walnuts Juglans regia and Juglans rupestris have the greatest thickness of the leaf blades. For this reason, they have the greatest thickness of palisade and spongy mesophylls, comparing with that of other species (Table-1). Mesophyll of the all walnuts including: J.regia, J.rupestris, J. mandshurica, J. sieboldiana, J.cinerea, J. nigra - multilayer. Coefficients of palisade mesophylls of the walnuts Juglans regia and Juglans rupestris are significantly smaller than the other species' coefficent. Volumes of columnar mesophyll cells of the walnuts J. regia, $J$. cinerea, J. nigra are the significantly smallest one. However, the shape of the palisade mesophyll cells has more important significance. The more elongate cell shape, the larger area per unit cell volume occurs. The columnar cells of the walnut Juglans regia have more elongate shapes than cells of other species have (Table-2).

Leaf anatomy of the species of the genus Juglans $L$ in the conditions of Belgorod oblast.

\begin{tabular}{|c|c|c|c|c|c|c|}
\hline Specie & $\begin{array}{c}\text { Leaf thickness, } \\
\mu \mathrm{m}\end{array}$ & $\begin{array}{c}\text { Number of the } \\
\text { palisade } \\
\text { tissue layers }\end{array}$ & $\begin{array}{c}\text { Number of the } \\
\text { spongy } \\
\text { tissue layers }\end{array}$ & $\begin{array}{c}\text { Thickness of } \\
\text { palisade } \\
\text { mesophyll, } \mu \mathrm{m}\end{array}$ & $\begin{array}{c}\text { Thickness of } \\
\text { spongy } \\
\text { mesophyll, } \mu \mathrm{m}\end{array}$ & $\begin{array}{c}\text { Coefficient of } \\
\text { palisade } \\
\text { mesophyll, } \%\end{array}$ \\
\hline J. mandshurica & $\begin{array}{c}102.64 \pm 1.94 \\
* *\end{array}$ & $2.0 \pm 0 *$ & $3.43 \pm 0.053 * *$ & $\begin{array}{c}50.80 \pm 0.627 \\
* *\end{array}$ & $\begin{array}{c}28.86 \pm 0.583 \\
* *\end{array}$ & $\begin{array}{c}92.38 \pm 2.74 \\
* *\end{array}$ \\
\hline J. sieboldiana & $\begin{array}{c}109.04 \pm 1.27 \\
* *\end{array}$ & $2.35 \pm 0.050$ & $4.0 \pm 0.058 * *$ & $\begin{array}{c}63.63 \pm 0.851 \\
* *\end{array}$ & $\begin{array}{c}35.84 \pm 0.773 \\
* *\end{array}$ & $\begin{array}{c}92.37 \pm 2.97 \\
* *\end{array}$ \\
\hline J. regia & $149.13 \pm 2.05$ & $2.45 \pm 0.067$ & $4.8 \pm 0.092$ & $83.55 \pm 1.41$ & $63.92 \pm 1.78$ & $56.88 \pm 0.683$ \\
\hline J. rupestris & $151.19 \pm 1.39$ & $2.1 \pm 0.026^{*}$ & $4.05 \pm 0.045 * *$ & $\begin{array}{c}71.34 \pm 1.62 \\
* *\end{array}$ & $61.17 \pm 0.979$ & $58.77 \pm 1.32$ \\
\hline J. cinerea & $\begin{array}{c}96.83 \pm 0.540 \\
* *\end{array}$ & $2.0 \pm 0 *$ & $3.6 \pm 0.04 * *$ & $\begin{array}{c}57.70 \pm 0.514 \\
* *\end{array}$ & $\begin{array}{c}35.06 \pm 0.341 \\
* *\end{array}$ & $\begin{array}{c}83.33 \pm 1.17 \\
* *\end{array}$ \\
\hline J. nigra & $\begin{array}{c}86.83 \pm 0.977 \\
* *\end{array}$ & $2.0 \pm 0.05^{*}$ & $4.0 \pm 0.047 * *$ & $\begin{array}{c}55.73 \pm 0.757 \\
* *\end{array}$ & $\begin{array}{c}34.29 \pm 0.461 \\
* *\end{array}$ & $\begin{array}{c}84.04 \pm 2.21 \\
* *\end{array}$ \\
\hline
\end{tabular}

* - significant differences at a probability level 0.95;

** - significant differences at a probability level 0.99, in comparison with J. regia.

Table 2

Characteristics of palisade mesophyll cells of the species of the genus Juglans $L$ in the conditions of Belgorod oblast.

\begin{tabular}{|c|c|c|c|}
\hline Specie & $\begin{array}{c}\text { Diameter of palisade } \\
\text { mesophyll cell, } \mu \mathrm{m}\end{array}$ & $\begin{array}{c}\text { Height of palisade } \\
\text { mesophyll cell, } \mu \mathrm{m}\end{array}$ & $\begin{array}{c}\text { Volume of palisade } \\
\text { mesophyll cell, } \mu^{3}\end{array}$ \\
\hline J. mandshurica & $35.15 \pm 6.34^{* *}$ & $25.40 \pm 1.18^{* *}$ & $12162.7 \pm 3900.35^{* *}$ \\
\hline J. sieboldiana & $40.15 \pm 3.88^{* *}$ & $27.64 \pm 1.45^{* *}$ & $17421.3 \pm 2696.34^{* *}$ \\
\hline
\end{tabular}

ISPC The Best of European Innovations, 


\begin{tabular}{|c|c|c|c|}
\hline J. regia & $11.13 \pm 1.29$ & $35.46 \pm 1.0$ & $4672.4 \pm 1187.79$ \\
\hline J. rupestris & $36.04 \pm 5.62^{* *}$ & $34.13 \pm 1.97$ & $25665.8 \pm 6468.32 * *$ \\
\hline J. cinerea & $42.15 \pm 7.30^{* *}$ & $28.85 \pm 1.41^{* *}$ & $9508.93 \pm 2870.77$ \\
\hline J. nigra & $57.84 \pm 3.34^{* *}$ & $22.77 \pm 1.38^{* *}$ & $9014.59 \pm 2136.07$ \\
\hline
\end{tabular}

* - significant differences at a probability level 0.95;

** - significant differences at a probability level 0.99, in comparison with J. regia.

Adaptive features of leaf structure. Classification of trichomes: Non-glandular unicellular trichomes (Fig. 1) are found on the adaxial and abaxial leaf epidermis of the walnut $J$. cinerea. They are sickle-shaped with length $319.23 \pm$ $44.13 \mu \mathrm{m}$. (Fig.2, a). The unicellular trichomes of the walnut J. sieboldiana are rarely found on the abaxial and adaxial epidermis, but only found on the veins (length: $327.39 \pm 25.84 \mu \mathrm{m}$ ). Trichomes of the walnut $J$. mandshurica evenly arrange on the abaxial and adaxial epidermis (length $373.88 \pm 44.32 \mu \mathrm{m}$ ). Unicellular conical -shaped trichomes of J. nigra are rarely found on the abaxial epidermis (length: 91.19 $\pm 10.11 \mu \mathrm{m})$.

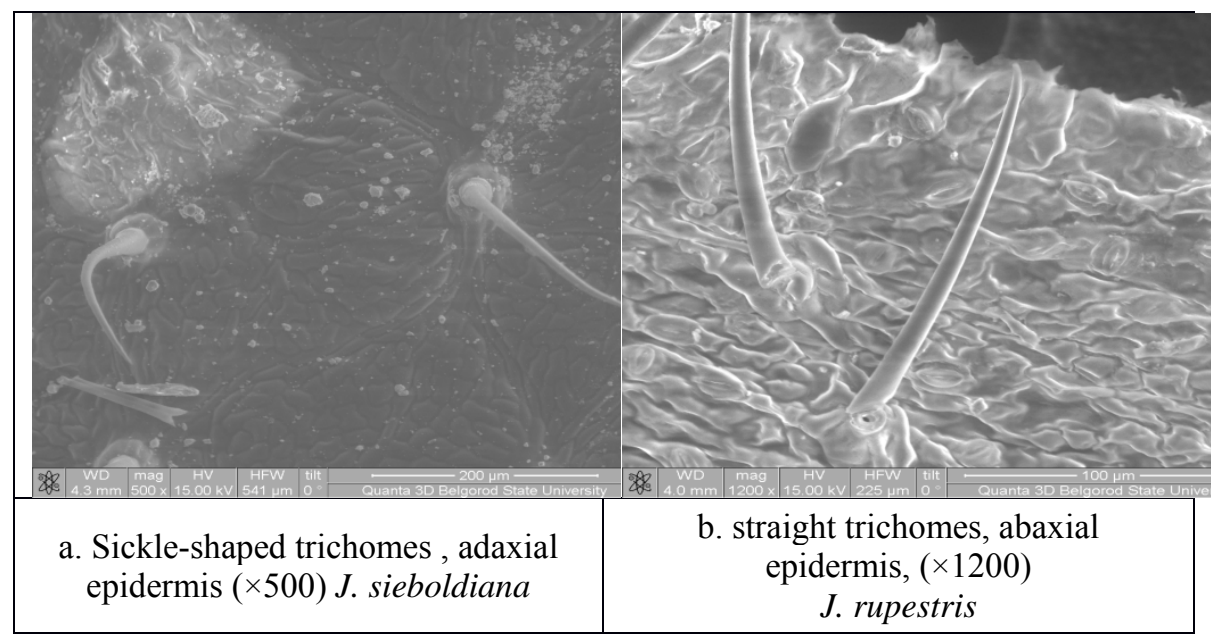

Figure 1 - The shape of non-glandular unicellular trichomes of the species of the genus Juglans $L$.

Sophisticated single-row unbranched conical hairs are found on the adaxial and abaxial epidermis of the walnut Juglans sieboldiana (Fig. 1, 2) (length $122-200 \mu \mathrm{m})$. They are uniformly distributed on adaxial epidermis. They are mostly found on the veins of the abaxial epidermis. Multicellular singlerow trichomes of the Juglans rupestris are only found on the abaxial epidermis. They are straight, evenly distributed (length $150.56 \pm 15.5 \mu \mathrm{m}$ ). Nonglandular sophisticated tufted trichomes have the length of branches varying from 125 to $560 \mu \mathrm{m}$, the diameter of the multicellular base is $47.24 \pm 2.50 \mu \mathrm{m}$. (Fig.2d). Number of branches of the sophisticated tufted trichomes is 2-8, those of branched trichomes- 8-15 (Fig 2.c). Tufted trichomes are found on the abaxial epidermis of the walnuts $J$. cinerea,
Juglans sieboldiana, J. mandshurica. Branched trichomes are found on the vein of the adaxial and abaxial surfaces of the walnut Juglans sieboldiana. Highly significant linear correlation between the length and the number of branches $(r=0,833)$ was identified. We observed only sessile tufted trichomes for all species. Basic epidermal cells adjacent to the base of trichomes exhibit more different shape and size than the remaining cells of the epidermis. They have a trapezoidal shape. The cells at the base of hair covered with cuticle, outwardly resembling "cushion". According to the SEM, the surface of the hair does not form folds; however it well detected microrelief helically oriented relative to the vertical axis of the cell (Fig. 3). 
Impact Factor ISRA (India) $\quad=\mathbf{1 . 3 4 4}$

Impact Factor ISI (Dubai, UAE) $=\mathbf{0 . 8 2 9}$

based on International Citation Report (ICR)

Impact Factor GIF (Australia) $=\mathbf{0 . 3 5 6}$
Impact Factor JIF $\quad=\mathbf{1 . 5 0 0}$

Impact Factor SIS (USA) $\quad=\mathbf{0 . 4 3 8}$

Impact Factor РИНЦ (Russia) $=0.179$

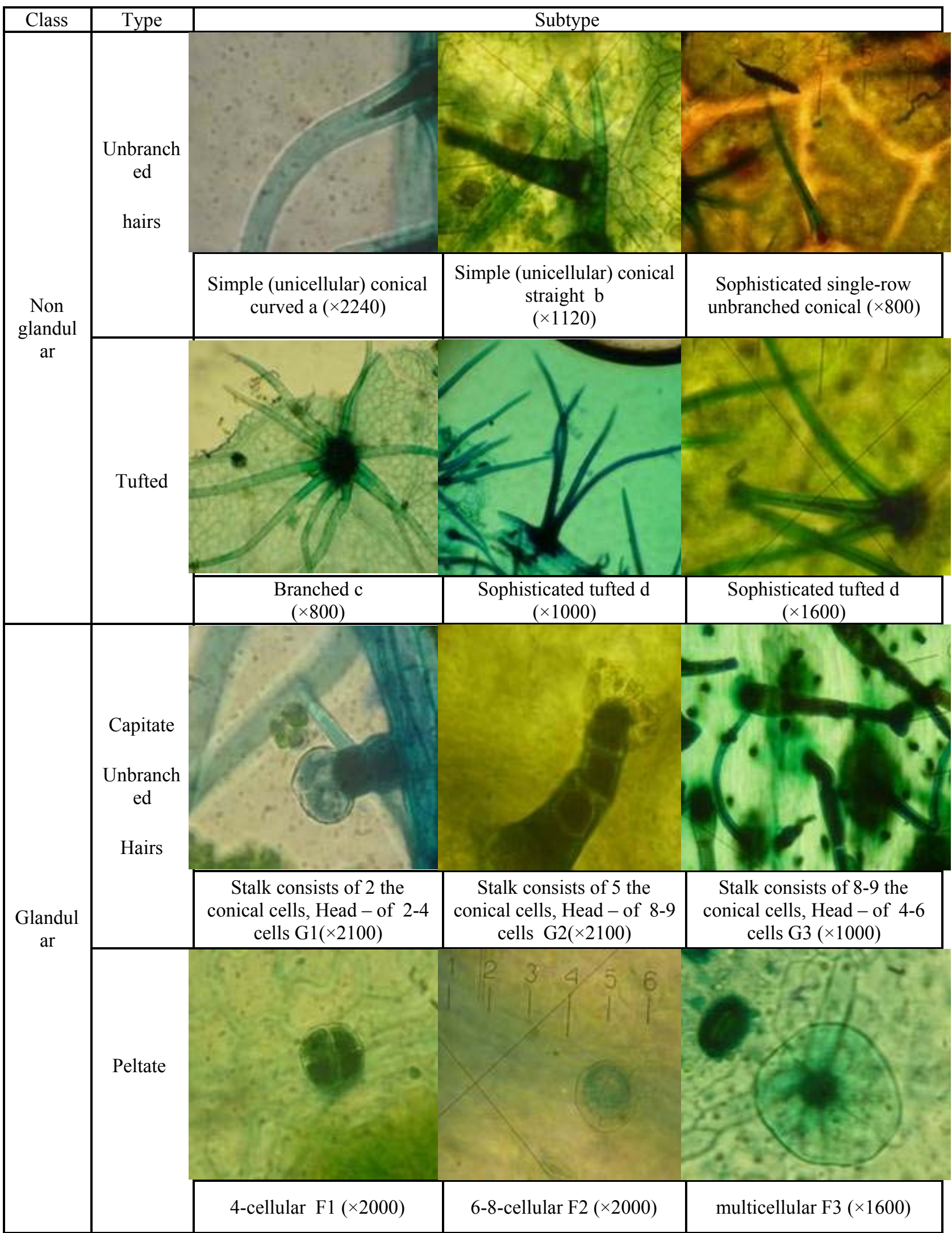

Figure 2 - Morphological classification of trichomes of the genus Juglans L.

ISPC The Best of European Innovations,

Gothenburg, Sweden 


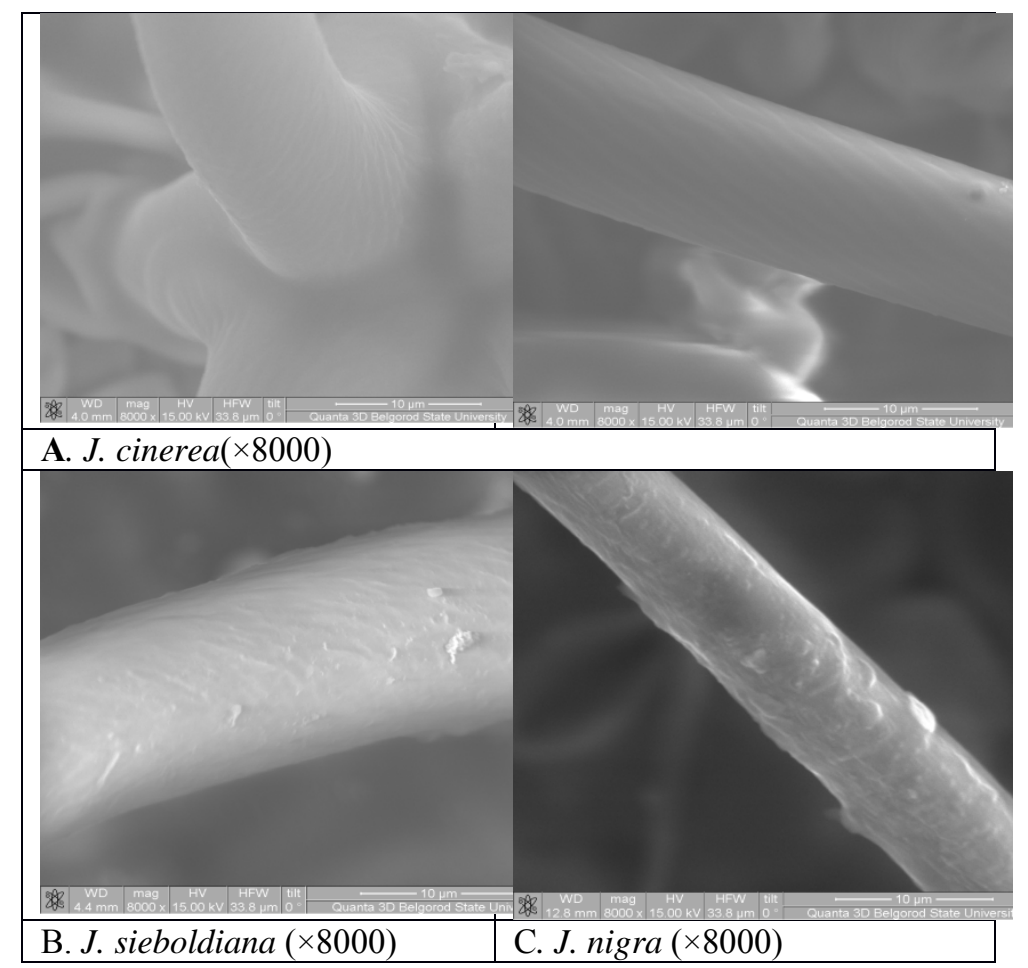

Figure 3 - The surface microrelief of non-glandular trichomes of the genus Juglans L.

Capitate trichomes are found on the adaxial and abaxial epidermis of all species of nuts, except $J$. regia. Capitate trichomes are on short stalk (Fig. 2, G1). Small capitate trichomes of the walnut J.cinerea consisting of 2-cellular stalk and 2 -4 cellular head, are found on adaxial and abaxial leaf surface. The capitate trichomes of the walnut $J$. sieboldiana on the two-cell stalk are found on the veins of abaxial epidermis. Their heads contain of 6 to 12 cells; a large part thereof is damaged. Capitate trichomes of the walnut J.cinerea (Fig. 2, G2 )on the long 5celluar stalk (length of $120.42 \pm 15.70 \mu \mathrm{m}$ ), 3-4 cell head (diameter $93.1 \pm 3.17 \mu \mathrm{m}$ ) are located on the abaxial and adaxial epidermis. They are found only in the veins on the abaxial epidermis.

Glandular trichomes of the walnut $J$. sieboldiana are found on the veins of abaxial epidermis (the length of the stalks $54.37 \pm 3.14 \mu \mathrm{m}$, diameter of the head 77. $10 \pm 5.58 \mu \mathrm{m})$. Capitate trichomes of the walnut J.nigra characterized by the 6- cellular stalk (length $115.17 \pm 20.15 \mu \mathrm{m}), 7-8$ cellular head (diameter of $57.48 \pm 5,87 \mu \mathrm{m}$ ) on the adaxial epidermis (only in veins) and abaxial epidermis (evenly spaced) (Fig. 2, G3).

The walnut $J$. rupestris has the subtype of glandular trichomes on the abaxial and adaxial epidermis. The number of stalk cells in a range from
3 to 7 (length $56.35 \pm 8.24$ microns), most heads destroyed. Capitate trichomes of the walnut $J$. mandshurica having a long stalk on the adaxial and abaxial epidermis are located at the veins. The length of the stalks $44.69 \pm 5.45 \mu \mathrm{m}$, diameter of the head $64.49 \pm 11.11 \mu \mathrm{m}$.

Peltate trichomes are characteristics of plants of the family Juglandacea. They are 4, 8-cellular, as well as multicellular trichomes. 4-cellular trichomes are rarely found on the adaxial epidermis, but they are evenly arranged on the abaxial epidermis. Small peltate glands of J. sieboldiana are rarely observed on the adaxial epidermis, but found on the abaxial epidermis - 4-8 cellular (Table-3). Small peltate glands of the walnut J.nigra are found on the abaxial and adaxial epidermis with the diameter $400.74 \pm$ $39.20 \mu \mathrm{m}$. For the walnut J. mandshurica, small peltate glands are rarely located on the adaxial and abaxial epidermis. Multicellular peltate trichomes are observed in all the studied species of the genus Juglans L. The largest areas of multicellular peltate trichomes are observed in the walnut J. mandshurica, $J$. sieboldiana, J.cinerea and the smallest areas - the walnut J. regia and J. ruperstris. Peltate trichomes of the walnuts J.regia and $J$. sieboldiana have themost rounded shape, which corresponds to a greater fullness of their secret. 


\section{Characteristics of multicellular peltate trichomes of plants of the genus Juglans $L$.}

Table 3

\begin{tabular}{|c|c|c|c|c|}
\hline Specie & $\begin{array}{c}\text { Area of a peltate } \\
\text { gland } \times 10^{3} \mu \mathrm{m}^{2}\end{array}$ & $\begin{array}{c}\text { Area of a subcuticular } \\
\text { cavity of peltate gland. } \\
\mu \mathrm{m}^{2}\end{array}$ & $\begin{array}{c}\text { Coefficient of } \\
\text { eccentricity of } \\
\text { peltate gland }\end{array}$ & $\begin{array}{c}\text { Coefficient of } \\
\text { eccentricity of } \\
\text { subcuticular cavity of } \\
\text { peltate gland }\end{array}$ \\
\hline J. cinerea & $\begin{array}{c}9.845 \pm 0.321 \\
*\end{array}$ & $\begin{array}{c}5.5095 \pm 0.244 \\
* *\end{array}$ & $0.495 \pm 0.027 *$ & $0.505 \pm 0.032 * *$ \\
\hline J. sieboldiana & $\begin{array}{c}10.045 \pm 0.203 \\
* *\end{array}$ & $\begin{array}{c}4.259 \pm 0.290 \\
* *\end{array}$ & $0.325 \pm 0.030$ & $0.420 \pm 0.035$ \\
\hline J. mandshurica & $\begin{array}{c}11.876 \pm 0.131 \\
* *\end{array}$ & $\begin{array}{c}3.592 \pm 0.129 \\
* *\end{array}$ & $0.424 \pm 0.017$ & $0.227 \pm 0.016$ \\
\hline J. rupestris & $\begin{array}{c}3.363 \pm 0.410 \\
* *\end{array}$ & $\begin{array}{c}1.112 \pm 0.133 \\
*\end{array}$ & $0.560 \pm 0.039 * *$ & $0.558 \pm 0.046$ \\
\hline J. regia & $1.858 \pm 1.338$ & $0.162 \pm 0.117$ & $0.389 \pm 0.032$ & $0.494 \pm 0.047$ \\
\hline
\end{tabular}

Cuticular layer on the surface of peltate trichomes is thicker, it forms a special relief. Multicellular peltate trichomes often have radial folds along the anticlinal walls (J.cinerea,
J.sieboldiana). However, cuticle of the walnut J.nigra is thinner, waxy film on the surface of the epidermis is not expressed. Cuticle largely subsides around subcuticular cavity (Fig. 4 B)

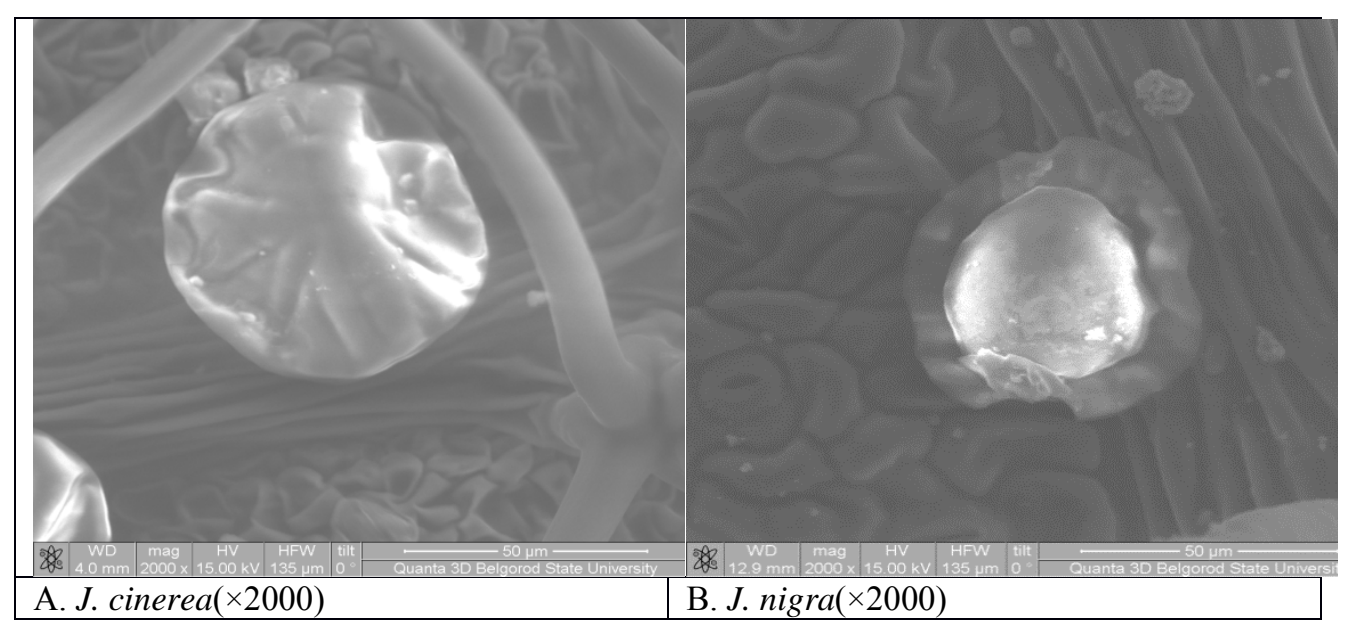

Figure 4 - Relief surface of cuticular layer of peltate trichomes of abaxial leaf surface of the species of the genus Juglans L.

Stomata: The regulation of water metabolism of plants is due to change in stomatal conductance [5-9]. Guard cells dominated the principal cells of the epidermis are found on the epidermis of the walnut
J.mandshurica, J. sieboldiana, J. cinerea. Stomata of the walnut Juglans regia, Juglans nigra are located in the same level with the main cells of the epidermis (Fig. 5). 


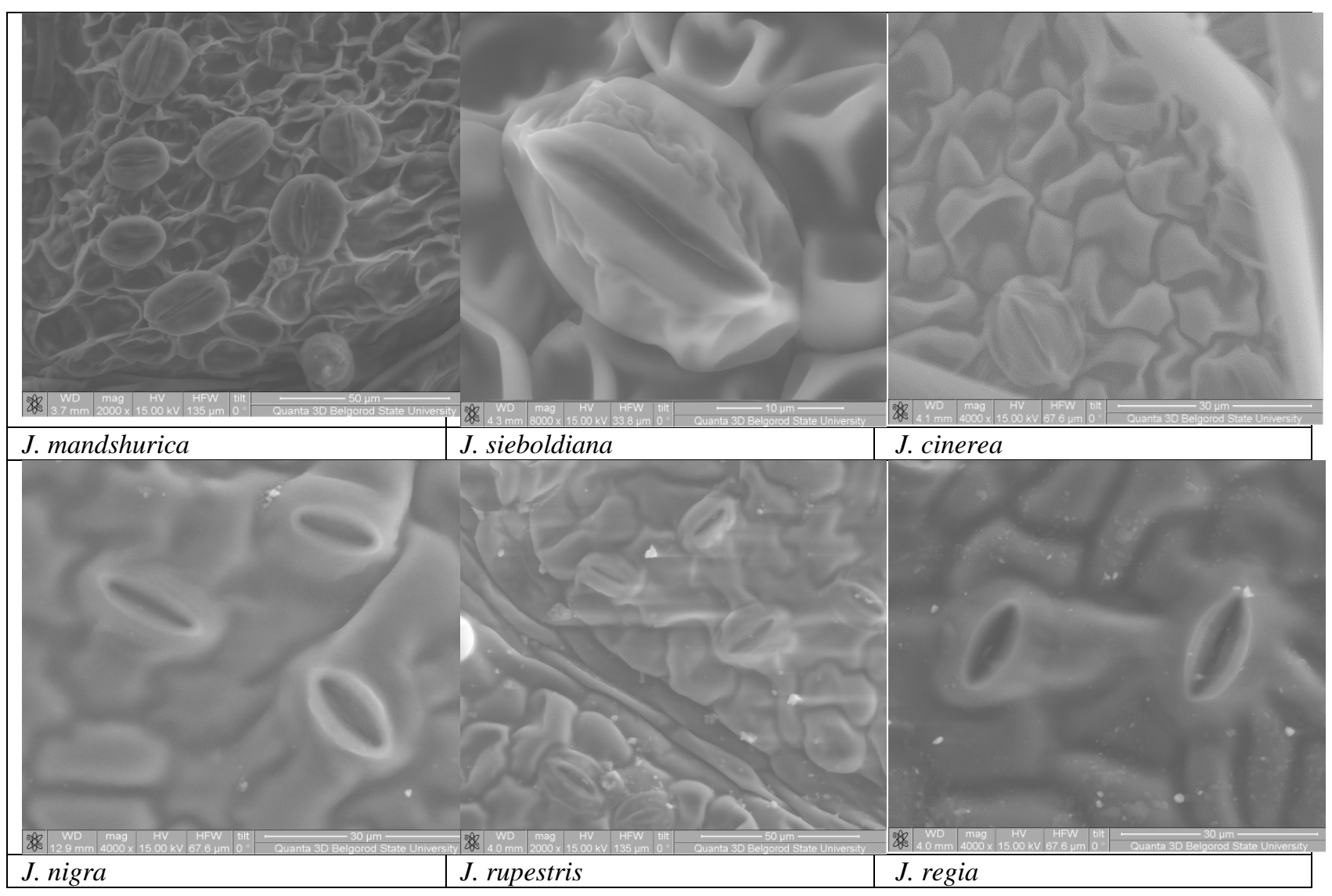

Figure 5 - Abaxial leaf epidermis of the genus Juglans. L.

While xeromorphic leaves increase, number of stomata per unit area decreases. The highest concentrations of stomata are observed on the lower leaf surface of the walnut $J$. mandshurica, $J$. sieboldiana, $J$. rupestris, and the smallest concentrations of stomata - the walnuts $J$. regia, $J$. cinerea. Increasing xerophyte structure of the leaf blade is marked reduction in the size of the stomata. In our experiment, no significant direct relationship was obtained between the size of the stomata and drought tolerance parameters. The smallest areas of stomata are observed in the walnut J. nigra, J. sieboldiana, J.regia and J. mandshurica. The decrease in stomatal resistance is associated with an increase in the rate of photosynthesis. The lowest capacities stomata are observed in the walnut $J$. regia, J. nigra and $J$. rupestris (Table-4). The greatest degrees of openness of the stomata are observed in the walnut $J$. mandshurica and $J$. sieboldiana, which have high transpiration rate and moisture loss during a six-hour wilting.

Table 4

Stomatal parameters of the leaf of the species of the genus Juglans $\mathrm{L}$ in the conditions of Belgorod oblast.

\begin{tabular}{|c|c|c|c|}
\hline Specie & Stomatal area. $\mu \mathrm{m}^{2}$ & DOS & $\begin{array}{c}\text { Stomatal number per unit leaf area } \\
1 \mathrm{MM}^{2}\end{array}$ \\
\hline J. mandshurica & $265.82 \pm 8.64$ & $10.47 \pm 1.35$ & $150.0 \pm 13.50$ \\
\hline J. sieboldiana & $278.50 \pm 17.29$ & $15.35 \pm 3.30^{*}$ & $155.5 \pm 33.0$ \\
\hline J. regia & $274.55 \pm 17.25$ & $6.17 \pm 1.65$ & $81.3 \pm 33.0$ \\
\hline J. rupestris & $375.57 \pm 13.43^{* *}$ & $8.74 \pm 0.466$ & $120.3 \pm 4.66$ \\
\hline J. cinerea & $357.54 \pm 16.89^{*}$ & $7.91 \pm 1.27$ & $101.5 \pm 9.58$ \\
\hline J. nigra & $250.62 \pm 11.27$ & $8.12 \pm 0.958$ & \\
\hline
\end{tabular}

* _ significant differences at a probability level 0.95;

** - significant differences at a probability level 0.99, in comparison with J. regia;

DOS - the degree of openness of the stomata. 
Features of cuticle layer: The leaves of J. regia, J. nigra, J. rupestris are covered with a thick layer of cuticle, which thickens on the epidermal cells adjoining to the guard cells of stomata. Longitudinally oriented microfibrils of the walnut $J$. mandshurica, J. cinerea, J. sieboldiana were detected in the study of the ultrastructure of the guard cell walls. Their diameters are in the range 430.37$677.26 \mathrm{~nm}$. Microfibrils of the walnut J. regia, J. rupestris, J. nigra on the surface of guard cells are hardly distinguishable due to the thick cuticle layer (Fig. 3). Cuticle forms radial folding from the base of trichomes and around large stomata. Cuticle on the adaxial leaf surface is thicker than one on the abaxial (Fig. 4). It is mostly observed in the walnut J. regia, $J$. rupestris, J. nigra, J. sieboldiana. The waxy coating is unevenly distributed on the leaf surface of the walnut $J$. nigra. However, it is evenly distributed on the leaf surface of the walnut $J$. regia and $J$. sieboldiana.

Stomata form differs in various species of the genus Juglans L: the walnut $J$. mandshurica has almost circular shape of stomata; the walnut $J$. cinerea, J. nigra and J. sieboldiana - oval shape; the walnut $J$. regia - elongated oval shape.
Ecological features of some species of the genus Juglans $L$ introducing in conditions of Belgorod oblast.

Phenophases of some species of the genus Juglans L: In 2011, the vegetation period of the walnuts $J$. rupestris, J. nigra., J. cinerea, J. regia, J. manshurica began in early May, and J. sieboldiana in the third decade of April (Table-5). Phenological observations revealed the plant with only staminate, pistillate flowers or with bisexual flowees. $8 \%$ of the test plants $J$. manshurica had only pistillate flowers, $83 \%$ - the staminate flowers, $8 \%$ - did not have flowers. The walnuts $J$. rupestris had only staminate flowers, J.nigra - pistillate flowers. $10 \%$ of the walnut $J$. sieboldiana had only staminate flowers, $33 \%$ - only pistillate flowers, $44 \%$ - did not bloom this year. $25 \%$ of the walnut $J$. regia did not bloom, $23 \%$ - had only pistillate flowers, $3 \%$ had only staminate flowers, $49 \%$ plants had both pistillate and staminate flowers.

Budding phase in most species began in early first or second decade of May, flowering in early second or third decade of May. Staminate flowers bloomed earlier than pistillate flowers did (Tab-5).

Phenology of the species of the genus Juglans L.

Table 5

\begin{tabular}{|c|c|c|c|c|c|c|c|c|c|}
\hline \multirow[t]{3}{*}{ Species } & \multicolumn{9}{|c|}{ Phenophases } \\
\hline & \multirow{2}{*}{$\begin{array}{l}\text { Breaking } \\
\text { leaf buds }\end{array}$} & \multirow{2}{*}{\begin{tabular}{|l|} 
First leaf \\
beginning
\end{tabular}} & \multirow{2}{*}{\begin{tabular}{|l|} 
Third leaf \\
beginning
\end{tabular}} & \multirow{2}{*}{$\begin{array}{l}\text { Budding } \\
\text { beginning }\end{array}$} & \multicolumn{2}{|c|}{ Flowering } & \multirow{2}{*}{\begin{tabular}{|c|} 
Fruits \\
beginning \\
\end{tabular}} & \multirow{2}{*}{$\begin{array}{l}\text { Ripe fruits } \\
\text { beginning }\end{array}$} & \multirow[t]{2}{*}{ Defoliation } \\
\hline & & & & & $\underset{\mathrm{g}}{\operatorname{beginnin}}$ & ending & & & \\
\hline \multirow[t]{2}{*}{$\begin{array}{c}J . \\
\text { mandshurica }\end{array}$} & \multirow[t]{2}{*}{$1.05-5.05$} & \multirow[t]{2}{*}{$2.05-7.05$} & \multirow[t]{2}{*}{$3.05-4.05$} & $\begin{array}{l}\text { ठ } 7.05- \\
15.05\end{array}$ & $\begin{array}{l}10.05- \\
19.05 \\
\end{array}$ & $\begin{array}{l}19.05- \\
24.05 \\
\end{array}$ & \multirow[t]{2}{*}{$\begin{array}{l}24.05- \\
29.05\end{array}$} & \multirow[t]{2}{*}{15.09} & \multirow[t]{2}{*}{21.07} \\
\hline & & & & q 17.05 & 20.05 & 29.05 & & & \\
\hline J. rupestris & 3.05 & $1.05-4.05$ & 11.05 & गे 12.05 & \multicolumn{2}{|c|}{$15.05-25.05$} & 2.06 & 15.09 & 7.10 \\
\hline J. nigra & 2.05 & & 3.05 & q21.05 & \multicolumn{2}{|c|}{$25.05-13.06$} & 13.06 & - & 1.10 \\
\hline \multirow[t]{2}{*}{ J. cinerea } & \multirow[t]{2}{*}{$1.05-4.05$} & \multirow[t]{2}{*}{3.05} & \multirow[t]{2}{*}{4.05} & $\begin{array}{c}\text { ô } 5.05- \\
6.05\end{array}$ & $\begin{array}{l}10.05- \\
14.05\end{array}$ & $\begin{array}{l}16.05- \\
19.05\end{array}$ & \multirow[t]{2}{*}{$28.05-2.06$} & \multirow[t]{2}{*}{25.09} & \multirow[t]{2}{*}{23.09} \\
\hline & & & & $\begin{array}{c}+16.05- \\
17.05\end{array}$ & $\begin{array}{l}16.05- \\
17.05\end{array}$ & $\begin{array}{c}28.05- \\
3.06\end{array}$ & & & \\
\hline \multirow{2}{*}{$\begin{array}{c}J . \\
\text { sieboldiana }\end{array}$} & \multirow[t]{2}{*}{28.04} & \multirow[t]{2}{*}{ 28.04-1.05 } & \multirow[t]{2}{*}{$1.05-2.05$} & ๙ิ 6.05 & 8.05 & 29.05 & \multirow{2}{*}{$\begin{array}{l}28.05- \\
30.05\end{array}$} & \multirow[t]{2}{*}{15.09} & \multirow[t]{2}{*}{23.09} \\
\hline & & & & o 17.05 & 19.05 & $\begin{array}{l}28.05- \\
30.05\end{array}$ & & & \\
\hline \multirow[t]{2}{*}{ J. regia } & \multirow[t]{2}{*}{$2.05-6.05$} & \multirow[t]{2}{*}{$2.05-9.05$} & \multirow[t]{2}{*}{$4.05-11.05$} & $\begin{array}{l}\text { ô } 1.05- \\
13.05\end{array}$ & $\begin{array}{l}7.05- \\
15,05\end{array}$ & $\begin{array}{l}15.05- \\
30.05\end{array}$ & \multirow[t]{2}{*}{$20.05-5.06$} & 7.10 & 10.10 \\
\hline & & & & $\begin{array}{c}+13.05- \\
20.05\end{array}$ & $\begin{array}{l}16.05- \\
22.05\end{array}$ & $\begin{array}{c}20.05- \\
5.06\end{array}$ & & & \\
\hline
\end{tabular}

Defoliation of the species of the walnut Juglans $\mathrm{L}$ varied considerably. We observed that the leaves of the walnut $J$. mandshurica early started yellowing and falling, due to its low drought tolerance. Defoliation of the walnuts J. cinerea, J. sieboldiana were observed in the second, third decades of 
September and J. regia, J.nigra, J. rupestris - in early October.

Abiotic factors: Drought tolerance is the ability of a plant body as little as possible to modify the metabolism in inadequate water supply [1-4]. As can be seen from (Table-6) that water content of leaves of the species J.regia, J.nigra exceeds $70 \%$, which is typical for plants with a high degree of drought tolerance. Loss of water of leaves from wilting after six hours of the walnut J.regia does not exceed $30 \%$, which corresponds to plants with high drought resistance ; the walnut J.nigra, J. rupestris (not exceed $40 \%$ ) - an average degree of drought tolerance. One of the key indicators in assessing the degree of drought tolerance is the degree of leaf damage after a six-hour wilting. The smallest degree of leaf damage is observed in the walnuts J.regia, J.nigra, J. rupestris.

Table 6

Characteristics of the water regime of the leaves and the degree of relative drought tolerance of the species of the genus Juglans $\mathbf{L}$.

\begin{tabular}{|c|c|c|c|c|c|c|c|}
\hline \multirow[t]{2}{*}{ Specie } & \multirow[t]{2}{*}{$\begin{array}{l}\text { Water } \\
\text { content, } \%\end{array}$} & \multirow[t]{2}{*}{$\begin{array}{l}\text { Water deficit, } \\
\%\end{array}$} & \multicolumn{4}{|c|}{$\begin{array}{l}\text { Water lost after leaf wilting , \% of water } \\
\text { content }\end{array}$} & \multirow[t]{2}{*}{$\begin{array}{l}\text { Drought resistance, } \\
\text { point }\end{array}$} \\
\hline & & & After $2 \mathrm{~h}$. & After $4 \mathrm{~h}$. & After $6 \mathrm{~h}$. & $\begin{array}{l}\text { Degree of } \\
\text { damage, } \%\end{array}$ & \\
\hline J. mandshurica & $\begin{array}{l}65.82 \pm \\
1.78^{*}\end{array}$ & $\begin{array}{l}12.96 \pm \\
2.44\end{array}$ & $\begin{array}{l}40.33 \pm \\
1.65 * *\end{array}$ & $\begin{array}{l}66.59 \pm \\
1.88 * *\end{array}$ & $\begin{array}{l}76.28 \pm \\
1.94 * *\end{array}$ & $\begin{array}{l}90.33 \pm \\
4.38 * *\end{array}$ & 4 \\
\hline J. sieboldiana & \begin{tabular}{|l|}
$65.23 \pm$ \\
$1.42 *$
\end{tabular} & \begin{tabular}{|l}
$3.45 \pm$ \\
$0.998^{*}$
\end{tabular} & \begin{tabular}{|l|}
$27.40 \pm$ \\
$3.29 * *$
\end{tabular} & \begin{tabular}{|l|}
$51.12 \pm$ \\
$4.32 * *$
\end{tabular} & \begin{tabular}{|l|}
$68.11 \pm$ \\
$4.08 * *$
\end{tabular} & \begin{tabular}{|l}
$84.0 \pm$ \\
$3.56^{* *}$
\end{tabular} & 5 \\
\hline J. regia & $\begin{array}{l}70.59 \pm \\
1.12\end{array}$ & \begin{tabular}{|l|}
$17.86 \pm$ \\
6.19
\end{tabular} & $\begin{array}{l}9.10 \pm \\
0.687\end{array}$ & \begin{tabular}{|l|}
$17.23 \pm$ \\
1.30
\end{tabular} & \begin{tabular}{|l|}
$25.55 \pm$ \\
1.86
\end{tabular} & \begin{tabular}{|l|}
$25.55 \pm$ \\
6.46
\end{tabular} & 8 \\
\hline J. rupestris & $\begin{array}{l}65.70 \pm * * \\
0.521\end{array}$ & $\begin{array}{l}8.95 \pm \\
0.601\end{array}$ & $\begin{array}{l}16.88 \pm \\
1.82 * *\end{array}$ & \begin{tabular}{|l|}
$27.88 \pm$ \\
2.98
\end{tabular} & \begin{tabular}{|l|}
$39.60 \pm$ \\
$3.79 * *$
\end{tabular} & $\begin{array}{l}14.0 \pm \\
4.99\end{array}$ & 6 \\
\hline J. cinerea & \begin{tabular}{|l|}
$73.98 \pm$ \\
3.69
\end{tabular} & \begin{tabular}{|l|}
$25.45 \pm$ \\
3.91
\end{tabular} & $\begin{array}{l}24.42 \pm \\
0.947 * *\end{array}$ & \begin{tabular}{|l|}
$43.04 \pm$ \\
$1.46^{* *}$
\end{tabular} & \begin{tabular}{|l|}
$59.65 \pm$ \\
$1.79 * *$
\end{tabular} & \begin{tabular}{|l}
$92.33 \pm$ \\
$2.58 * *$
\end{tabular} & 4 \\
\hline J. nigra & \begin{tabular}{|l|}
$82.50 \pm$ \\
5.98
\end{tabular} & \begin{tabular}{|l|}
$28.93 \pm$ \\
1.47
\end{tabular} & $\begin{array}{l}10.63 \pm \\
0.81\end{array}$ & \begin{tabular}{|l|}
$21.61 \pm$ \\
1.61
\end{tabular} & \begin{tabular}{|l|}
$31.57 \pm$ \\
2.23
\end{tabular} & $\begin{array}{l}6.8 \pm \\
1.49\end{array}$ & 6 \\
\hline
\end{tabular}

* - significant differences at a probability level 0.95;

** - significant differences at a probability level 0.99, in comparison with J. regia

Leaves of the $J$. mandshurica had the greatest moisture loss, as a result, their leaf blades were damaged up to $90 \%$ of the total area. During the period of wilting, the walnuts J. regia, J. nigra, J. rupestris remained at the same level of water lost. The walnut J. regia, J. nigra, J. rupestris had significantly greater proportion of bound water than the other plant species (Fig. 6). The largest percentage of free water was observed in the leaves of $J$. mandshurica, which was characterized by the lowest water-holding capacity.

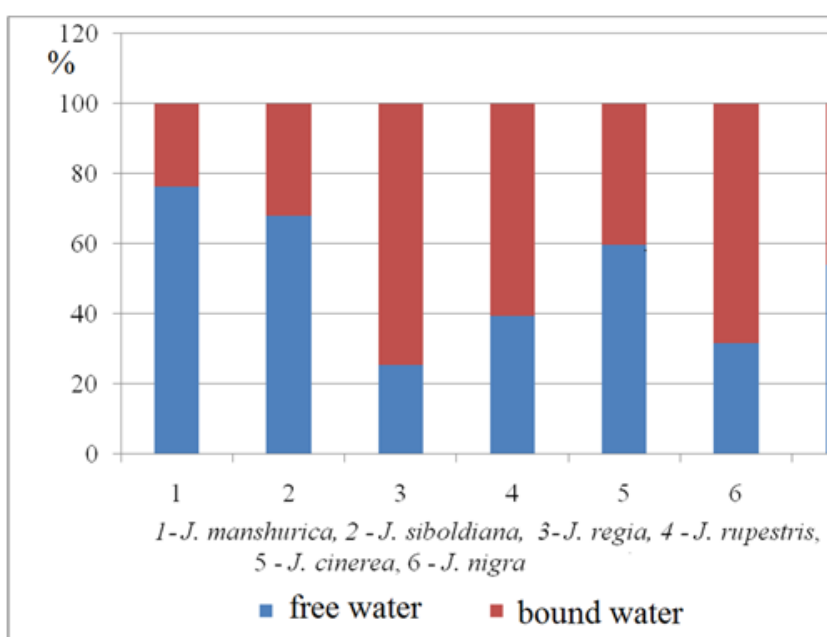

Figure 6 - The ratio of free and bound water in the leaves of the genus Juglans L. 
Drawings on a complex of indicators (method Nikitsky botanical garden), an average point of drought tolerance of various species were found. The highest degree of drought tolerance was observed in the walnut J. regia, J. nigra, and J. rupestris. Thus, J. regia had high water-holding capacity low transpiration rate and high water potential. The walnuts $J$. sieboldiana $J$. nigra and $J$. rupestris characterized with an average degree of drought tolerance. The walnuts J. Mandshurica, J. cinerea had indicators of drought tolerance, relating them to the plants with a low degree of drought tolerance. In the conditions of Belgorod oblast, they need watering.

Harvest was observed in five species of the genus Juglans $L$ : J. regia, J. manshurica, J. sieboldiana, J. cinerea and J. rupestris. All immature fruits of the $J$. nigra aborted. The walnut J. regia has rounded-cordate shape, while other walnuts such as $J$. manshurica, J. rupestris and J. cinerea are ovalheart-shaped form. They differ both in size and shape of the fruit. The shapes of all studied species are not perfectly rounded, so we decided to use multiple measurements in different directions (Table-7). Size of walnut kernel and a small thickness of the shell have economic value. Nuts of the walnut J. regia have a small mass, but the kernel mass is significantly high, due to its light shell (Table-7). The thickest shells are observed in the J. manshurica, and the kernel mass is low, a small mass of the walnut kernel was observed in walnut $J$. cinerea. The walnut $J$. sieboldiana differs in significantly high mass of the kernel and small thickness of the shell. The walnuts $J$. rupestris and $J$. manshurica have single fruitlets with a small number of fruits (2-3). The walnut $J$. sieboldiana differs in the significantly highest number of fruits in the stems, compared with other species, while the walnut J.regia differs in a large number of fruits on the trees. The most productive forms are the walnut J.regia with harvest $-1.5-2.0 \mathrm{~kg}$, the number of fruitlets on tree is $83-150$. The walnut $J$. sieboldiana has fruitlets with 6-7 fully maturing nuts.

Characteristics of fruiting plants of the genus Juglans $L$.

Table 7

\begin{tabular}{|c|c|c|c|c|c|c|}
\hline Specie & Fruit weight (g) & Height $(\mathrm{cm})$ & & & $\begin{array}{l}\text { Kernel weight } \\
\text { (g) }\end{array}$ & $\begin{array}{c}\text { Shell thickness } \\
(\mathrm{cm})\end{array}$ \\
\hline J. ma & & & & & 1.32 & 0.7 \\
\hline$J . r L$ & 9.66 & 3. & 2. & 3* & 1.6 & 0.2 \\
\hline J. cinerea & $9.10 \pm$ & $4.46=$ & 2.66 & $2.61 \pm 0.019$ & $1.21 \pm 0.042 * *$ & $0.27 \pm 0.01 * *$ \\
\hline J. sieboldiana & 11. & $4.09=$ & 2.99 & 3.3 & $3.20 \pm 1.79$ & $0.25 \pm 0.01 * *$ \\
\hline J. regia & $7.78 \pm 0.348$ & $3.21 \pm 0.054$ & $2.70 \pm 0.077$ & $2.68 \pm 0.065$ & $2.98 \pm 0.172$ & $0.20 \pm 0$ \\
\hline
\end{tabular}

* - significant differences at a probability level 0.95;

** - significant differences at a probability level 0.99, in comparison with J. regia

\section{Conclusions}

1. In the Belgorod region, the genus Juglans $L$ has full rhythm of seasonal development, allowing them to cultivate in the local conditions. Phenological observations revealed plants with staminate, pistillate and bisexual flowers. Budding phase in most species begins in early first - second of May, flowering in early second -third of May. Staminate flowers bloom earlier than pistillate flowers.

2. Morphological characteristics of trichomes of some species complement the existing classification of structural formations of the epidermis of the genus Juglans $L$.

3. J. regia differs in high water-holding capacity, low transpiration rate and high water potential differs: the walnut $J$. regia is the nuts with a high degree of drought tolerance. Average degrees of drought tolerance are J. sieboldiana, J. nigra and $J$. rupestris. The walnuts $J$. mandshurica, J. cinerea belong to plants with a low degree of drought tolerance in conditions of Belgorod oblast.

4. The most promising for breeding are the walnuts $J$. regia and $J$. sieboldiana in the conditions of Belgorod region because $J$. rupestris, $J$. mandshurica, J. cinerea have fewer fruitlets on the trees with a small number of fruits.

\section{Acknowledgement}

The authors would like to thank Kolesnikov D.A from Center of Collective Use of Scientific Equipment of Belgorod State National Research University for his help in performing the experiments on the SEM Quanta 200 3D. 


\section{References:}

1. Goryshin TK (1989) Photosynthetic apparatus of plants and environmental conditions / TK Goryshin. - LA: LSU- 204p.

2. Ibragimov ZA (2009) Fruiting walnut in forest biocenosis / NAS of Azerbaijan. Baku. - № 5. pp. $60-62$.

3. Ionova EV (2009) Criteria for assessing the level of drought tolerance of winter wheat / Agricultural science. - №7. pp. 17-18.

4. Kouchnirenko MD (1991) Physiology of water exchange and drought tolerance / SN Chisinau: "Shtiintsa. - 307 p.

5. Kuznetsov MN, Golyshkin LV (2006) Adaptive response of stomatal apparatus of blackberry leaf on heavy metal pollution / Status and prospects of berry culture in Russia (Proceedings of Scientific and Technical Conf. June 19-22, 2006). - Eagle: Publishing VNLISPK. 344.

6. Nikolaev EA, Slavskii VA, Tishchenko VV (2007) Introduction and selection of walnut in Voronezhsoy region. Monograph .Voronezh state research :152.

7. Morgun VV, Kirizy DA, Shadchin TM (2010) Ecophysiological and genetic aspects of adaptation of crop plants to global climate change / Physiology and biochemistry of crop plants to global climate change. - V. 42, № 1. pp.3-21.

8. Pautov AA, Vasiliev VA (2010) The role of the main forms of epidermal cells in the leaf morphogenesis of representatives HAMAMELIDACEAE / Botanical Journal. V. 95, № 3. pp.338-345.

9. Pautov AA, Sapach JJ (2003) Microrelief of the surface of the leaf epidermis of flowering plants /XI Congress of Russian Botanical
Society. Botanical research. Barnoul. - №2. - 83 p.

10. Pautov AA, Yakovleva OV, Kolodyazhni SF (2002) Microrelief surface of leaves of the Populus (Salicaceae) / Botanical Journal. - V. 87, №1. pp.63-72.

11. Rezanova TA (2010) Morpho-anatomical and ecological features of Ribes americanum Mill. introducing in the south of Upland. Saratov $20 \mathrm{p}$.

12. Rezanova TA, Sorokopudov VN (2008) Some features of anatomical and morphological structure of Ribes americanum Mill. / "Biologically active compounds of natural origin: herbal medicine, pharmaceutical marketing, pharmaceutical technology, botany," Proceedings of the international scientificpractical. Conf., - Belgorod: BSU. pp.133-135.

13. Shvedova OE, Shmatko IG (1992) Structural and functional position of stomata under water and temperature stress / Physiology and biochemistry of cultivated plants. - № 2, T. 24.pp.107-116.

14. Vasiliev BR (1988) Leaf structure of woody plants in different climatic zones / Ed. VM Schmidt. - L.: Publishing. Leningrad University. - 208p.

15. Vasilyev NP, Vasin EA (2003) Characteristics of introducing species of the genus Juglans L/ Biological Diversity. Plant introduction. Proceedings of the Third International Scientific Conference (23-25 September 2003, St. Petersburg). pp.179-180.

16. Vasin EA (2002) Promising forms of walnuts for the Tula region / Reports of TAA. - Vol. 274. pp.444-448. 